\title{
DISTOMOLAR UNILATERAL SUPERIOR RETIDO - RELATO DE CASO CLÍNICO-CIRÚRGICO
}

Rafaella Sanches da COSTA, Leandro William KATCHAN, Christine TOEDTER, Lucienne ULBRICH

Dentes supranumerários são dentes adicionais à dentição humana normal provavelmente causada pela hiperatividade da lâmina dental. Os distomolares ou quartos molares têm a segunda maior prevalência dentre os supranumerários, superados apenas pelos incisivos centrais superiores. Têm também uma maior incidência na maxila e em pacientes do sexo masculino (NEVILLE et. al., 1998). A grande maioria dos distomolares apresenta características de dentes rudimentares podendo ocasionalmente ser encontrado em tamanho natural (DAMANTE et. al., 1986). Os autores relatam um caso clínico de quarto molar unilateral superior retido tratado cirurgicamente na clínica de cirurgia da Universidade Positivo de Curitiba. É importante a detecção precoce de dentes supranumerários visto a série de complicações que podem causar na dentição do paciente como diastemas, retardo ou impactação, posicionamento inadequado de dentes permanentes, erupção ectópica, reabsorção radicular, má-formação de dentes permanentes, desarranjo oclusal, desenvolvimento de cistos e tumores, cáries, pericoronarite subaguda, gengivite e periodontite (MARZOLA, 2005; NEVILLE et. al., 1998; TAY et. al., 1984; MOLITERNO et. al., 1988). No caso relatado, a indicação da remoção cirúrgica foi pela prevenção das complicações neurológicas, mecânicas, tumorais e infecciosas dos dentes retidos.

Palavras-chave: Dente supranumerário; Dente não-erupcionado; Cirurgia Bucal; Terceiro molar. 